\title{
EFFECTIVE TRANSFORMATIONAL LEADERSHIP BEHAVIOURS FOR MANAGING CHANGE
}

\author{
GIFT VINGER \\ FRANS CILLIERS \\ cillifvn@unisa.ac.za \\ Department of Human Resource Management \\ University of Johannesburg
}

\begin{abstract}
The South African higher education (HE) sector has been criticised for an apparent lack of leadership, calling into question the leaders' ability to manage change as a result of the recent mergers of HE institutions. The aim of this present research was to establish the frequency of exhibition of transformational leadership and its behaviours and its level in this sector, including the commonly manifesting themes and strategies that transformational leaders, as change agents, utilise to effect change in their organisations. The Multifactor Leadership Questionnaire was administered to $190 \mathrm{HE}$ leaders, followed by individual interviews. It was found that these leaders exhibit transformational leadership fairly often and that, contrary to criticism, they manage change fairly successfully.
\end{abstract}

Key words

Effective, transformational leadership behaviours, managing challenge, HE institutions

The study of leadership has recently become quite intense and diversified (Northouse, 2001). Thousands of empirical investigations of leaders have been conducted over the last 75 years. Still, no clarity has been reached as to what distinguishes leaders from non-leaders, or effective leaders from ineffective leaders (Bennis \& Nanus, 1997). It is intriguing that effective leadership, which is presently described as transformational leadership, has become a sine-qua-non in modern-day organisations (Yukl, 1998) without which the organisation's survival in times of turbulence and change would be almost unthinkable.

Transformational leadership has been studied within particular contexts or in relation to various variables. Examples are the effect of leadership on organisational culture (van Tonder, 1998); investigating the transformational leadership skills which are essential to mobilise people (Handford, 1999); the relationship between certain personality traits and transformational leadership (van Rensburg \& Crous, 2000); and the relationship of transformational leadership with locus of control (van Staden, Scheepers \& Rieger, 2000). Change is one such variable that can provide the context within which leadership can be studied (File, 2000). Organisations are constantly in a state of change, though to varying degrees, because change is itself a dynamic and ongoing process (van Rooyen, 2000) that needs to be managed.

This study investigated the problem of the apparent lack of leadership in the higher education (HE) sector in South Africa (SA), particularly the perception that there is a lack of transformational leadership in the public HE institutions. This will compromise the leaders' ability to manage change successfully. This problem was viewed from the perspective of the changing HE landscape in SA, in which institutions are being merged or incorporated as prescribed by the Higher Education Act, Act no. 101 of 1997 (Department of Education, 1997).

One of the potential consequences of these mergers is that the newly-formed institutions may be threatened by a lack of appropriate leadership. The view that a lack of such leadership is one of the root causes why institutions find themselves in a precarious situation is widely supported by scholars and role players in the HE sector. For example, Cloete, Bunting and Kulati (2000, p. 9) have stated that "owing to a lack of leadership and management capacity, these institutions find it difficult to establish a new direction for themselves and to attract new funds". The Minister of Education was reported to have said (in
Business Day of 12 March 1999), that "some of our vicechancellors are still using historical disadvantage as an unconvincing cover for the mess they have caused in their tertiary education institutions" (cited in Cloete et al., 2000, p. $10)$. Brunyee (2001, p. 1) has mentioned that, besides the rate of change in the sector a number of universities and technikons are also in some form of financial or leadership crisis, as may be perceived in the continuous media coverage. It has furthermore been recognised that one of the major failings of the South African HE sector, delaying its effective transformation, is a shortage of skilled leadership, problematic governance and a lack of adequate management capacity (Higher Education Leadership and Management Programme, 2004).

The aim of this present research was to establish the frequency of exhibition of transformational leadership and its behaviours and to ascertain its level in the sector, including the commonly manifesting themes and strategies that transformational leaders, as change agents, utilise to effect change in their organisations. The research was premised on the assumption that if leaders exhibit transformational leadership and its behaviours frequently, if not always, and if their level of transformational leadership is high, then they could manage change successfully.

The Full Range of Leadership Styles (FRL) (Bass, 1998) was adopted in that the transactional and laissez-faire leadership styles were also measured. Fundamental to the FRL model is that every leader exhibits each style to some extent, and the model represents how frequently a leader exhibits a particular style of leadership.

\section{Organisational change}

The phenomenon of change has become central in the management of the modern organisations and is one of the issues today (McLagan, 2002). Change is an inseparable part of organisations, and it will certainly not disappear or dissipate (Paton \& McCalman, 2001). Organisations no longer have a choice: they are confronted with pressures to change; otherwise this may lead to their downfall (Nicholson, 1993). Burns (1996 cited in Paton \& McCalman, 2001), argues that change is not itself a problem - the problem lies in an inability on the part of leaders to lead it. There is, Burns considers, a growing inability on the part of leaders to develop and reinforce their role and purpose within complex, dynamic and challenging organisations.

Organisational change in the present research refers to the transformation of HE institutions by way of merging them to 
create completely new institutions with new identities, structures, cultures, reward systems, information processes and work designs. Transformation, as opposed to crescive change, is a form of enacted change which is planned, the intention of which is to bring about significant changes in, for example, how an institution is led (Norris, 2001). Whilst transformation is purposefully planned to change organisational structures and relationships, crescive change is unplanned and occurs through a natural course of events. This transformational change is referred to as Large-Scale Organisational Change (Letford et al., 1990, cited in Dawson, 1994) and aims at overhauling the entire HE sector.

The National Plan for Higher Education (NPHE) which came into being in 2001 (Jansen, 2001) proposed the mergers and incorporations of public HE institutions, which constitutes "..... the most ambitious and comprehensive change programme in the world today" (Frans van Vught, Rector of the University of Twente and former director of the Centre for Higher Education Policy Studies, quoted by Cloete et al., 2000, p. 2). The question seems to be whether the leaders of HE institutions are ready to handle such massive change and if they exhibit the necessary transformational leadership behaviours to do so.

\section{Bass' theory of transformational and transactional leadership}

The concept "transformational leadership" was first coined by Downton in a work titled Rebel Leadership in 1973 (Bass \& Avolio, 1994). It emerged as an important approach to leadership, as evidenced by the classic work of the political sociologist James MacGregor Burns in 1978 entitled Leadership (Hughes, Ginnet \& Curphy, 1999). Burns' (1978) theory laid a solid foundation for the works of other scholars regarding this perspective on leadership theory (Conger \& Kanungo, 1998). Bass (1985) therefore builds on the earlier ideas of Burns (Engelbrecht, 2002; Yukl, 1998), although his theory is not necessarily consistent with Burns' (Northouse, 2001).

\section{Transformational leadership}

Transformational leadership is defined relative to the leader's effect on his/her followers, in which the latter feel trust, admiration, loyalty, and respect toward the former and followers are motivated to do more than they were originally expected to do (Avolio, 1999; Bass, 1985; 1998; Yukl, 1998). Bass identified four transformational leadership behaviours which represent four basic components or "I's" of transformational leadership (Avolio, 1999; Bass \& Avolio, 1992).

Idealised influence (charisma) arouses strong emotions from followers and identification with, and emulation of, the leader (Bass \& Avolio, 2001; Yukl, 1998) because leaders act as strong role models for followers (Avolio, 1994; Bass, 1998; Northouse, 2001). They also display very high moral standards and conduct themselves in an ethical manner, and can thus be counted on to do the right thing (Bass \& Avolio, 1994; Northouse, 2001).

Individualised consideration involves providing support, encouragement, coaching (Avolio, 1999; Bass, 1998; Yukl, 1998), delegation, advice, and feedback for use in the personal development of followers (Bass \& Avolio, 1992).

Intellectual stimulation increases awareness of problems and influences followers to view problems from a new point of view (Yukl, 1998). Followers are stimulated to be creative and innovative and also to challenge their own beliefs and values and those of their leaders and organisation (Bass \& Avolio, 2001).In addition they are also encouraged to take intellectual risks and to question assumptions (Avolio, 1994; Bass, 1998).

Inspirational motivation includes developing and communicating an appealing vision (Avolio, 1994), using symbols and images (Bass \& Avolio, 2001) to focus the efforts of subordinates, and modelling behaviours that are deemed appropriate (Yukl, 1998).
Bass (1998) argues that when one organisation acquires another, the employees of the acquired organisation may be disturbed by a loss of identity and purpose. This may lead to anxiety, anger, depression and helplessness. Resignations, forced departures and threats to one's own security may also occur. People may be obsessed with survival in the merged organisation. Transformational leadership is therefore needed, so as to deal with the merging of the cultures of the acquired organisation and the organisation which is taking over, transcending both organisations. To help cope with the stress of the merger support, consideration and commitment are needed. Transformational leadership can assist followers and colleagues to alleviate the tensions of disengagement; the difficulty in disengaging from the old situation; disenchantment with the new arrangements; disorientation without the anchors of the past; and aid them to work through their denial and anger.

\section{Transactional leadership}

Transactional leadership concerns exchanges or transactions which are based on leaders discussing their role requirements with followers and specifying the rewards the latter will receive if they meet those requirements (Bass \& Avolio, 1994, cited in Engelbrecht, 2002). Bass also identified transactional leadership behaviours, which are described below.

Contingent reward involves an exchange process between the leaders and followers in which specific rewards are exchanged for follower effort. The leader endeavours to obtain agreement from followers regarding what should be done, accompanied by appropriate payoff (Northouse, 2001) or avoidance of punishment (Bass, 1985).

Management-by-exception (active and passive) involves corrective criticism, negative feedback, and negative reinforcement (Northouse, 2001).

Bass is an advocate of what is termed the transformational/ transactional continuum. The two leadership styles should be viewed as a single continuum rather than as mutually independent continua (Yammarino, 1993, cited in Northouse, 2001). Transformational leadership does not necessarily detract from transactional leadership but rather builds on it, thereby broadening the effects of the leader on effort and performance (Bass, 1998). These two are also distinct entities but not mutually exclusive processes. The same leader may use both styles at different times in different situations (Bass \& Avolio, 1992; Yukl, 1998) or in different amounts and intensities (Bass, 1985). Leaders can thus act both transformationally and transactionally (Conger \& Kanungo, 1998).

\section{Laissez-faire leadership}

Laissez-faire leadership is non-leadership, where a leader abdicates responsibilities and avoids making decisions (Bass, 1998).

\section{RESEARCH DESIGN}

\section{Research approach}

Methodological triangulation was adopted. Following on Creswell (1994) and Lee (1999), the design used is dominant-lessdominant in that this research is presented within a single, dominant quantitative paradigm, with a small component of the overall research being drawn from the qualitative paradigm. The triangulation is sequential in that the use of the interview is informed by and based on the results of the questionnaire.

\section{Research methodology}

Participants

Since the HE institutions were being reduced from 36 to 23 by means of the mergers and incorporations (Department of Education, 2001), seven affected institutions have been selected as the primary sampling units, viz. Technikon Free State (now Central University of Technology, Free State); University of the 
Free State; Vista University (unbundled); Potchefstroom University and University of North West (now North-West University); Rand Afrikaans University (RAU) and Technikon Witwatersrand (now University of Johannesburg). Thus, this study involved complex samples in which different levels of sampling units are employed (Babbie \& Mouton, 2001).

The sample, which is the secondary or final sampling unit, consisted of senior leaders drawn from the seven institutions (N $=190$ ). The senior leaders included vice-chancellors, deputy vice-chancellors, registrars, executive deans, deans, heads/chairs of departments/schools, executive directors, chief directors, senior directors, directors, managers and campus heads. The inclusion of these categories of leaders was based on the premise that transformational leadership is not confined to the occupants of the highest or most prominent positions in terms of influencing others (Bass \& Avolio, 1994) - such leaders can be found at all levels of the organisation's hierarchy (Avolio, 1999).

The gender composition of the sample was strongly biased towards males $(72,1 \%$ male $/ 24.7 \%$ female $)$. Its racial composition was highly skewed towards Whites (78.4\% White, $16.3 \%$ Black, 1,6\% Coloured and 1,1\% Indian). The mean age was 49.66 years $(\mathrm{SD}=9.31)$ which showed a trend towards older people, characteristic of senior leadership levels in organisations (minimum age $31 /$ maximum age 65 ). Tenure in the respective leadership positions fluctuated between $1(14.2 \%)$ and $9+$ years (46.8\% between 2 and 5; $15.9 \%$ between 6 and 8; 22,6\% 9+ years). Vice-chancellors constituted the fewest number of subjects $(1,1 \%)$ whilst heads/chairs of departments/schools constituted the largest number (50.5\%). Table 1 summarises the biographical characteristics of the sample.

TABLE 1

BIOGRAPHICAL CHARACTERISTICS $(\mathbf{N}=190)$

\begin{tabular}{|c|c|c|}
\hline VARIABLE & FREQUENCY & PERCENTAGE \\
\hline Male & 137 & 72,1 \\
\hline Female & 47 & 24,7 \\
\hline Missing values & 6 & 3,2 \\
\hline Total & 190 & 100 \\
\hline \multicolumn{3}{|l|}{ Racial Group } \\
\hline White & 149 & 78,4 \\
\hline Black & 31 & 16,3 \\
\hline Coloured & 3 & 1,6 \\
\hline Indian & 2 & 1,1 \\
\hline Missing values & 5 & 2,6 \\
\hline Total & 190 & 100 \\
\hline \multicolumn{3}{|l|}{ Age } \\
\hline $31-40$ & 21 & 11,1 \\
\hline $41-50$ & 71 & 37,4 \\
\hline $51-60$ & 69 & 36,3 \\
\hline $61-70$ & 16 & 8,4 \\
\hline Missing values & 13 & 6,8 \\
\hline Total & 190 & 100 \\
\hline \multicolumn{3}{|l|}{ Years of experience } \\
\hline $0-1$ & 27 & 14,2 \\
\hline $2-5$ & 89 & 46,8 \\
\hline $6-8$ & 30 & 15,9 \\
\hline 9 and above & 43 & 22,6 \\
\hline Missing values & 1 & 0,5 \\
\hline Total & 190 & 100 \\
\hline \multicolumn{3}{|l|}{ Leadership category } \\
\hline Vice-Chancellor & 2 & 1,1 \\
\hline Deputy Vice-Chancellor & 9 & 4,7 \\
\hline Registrar & 7 & 3,7 \\
\hline Dean (Executive Dean etc.) & 22 & 11,6 \\
\hline Head/Chair of Dept/School & 96 & 50,5 \\
\hline Director (Executive, Chief, Senior, etc.) & 41 & 21,6 \\
\hline Manager & 9 & 4,7 \\
\hline Campus Head & 3 & 1,6 \\
\hline Missing values & 1 & 0,5 \\
\hline Total & 190 & 100 \\
\hline
\end{tabular}

\section{Data collection technique}

The following two measuring instruments were used.

The Multifactor Leadership Questionnaire, Form 6-S

For the quantitative study, the shortened form of Northouse' (2001) Multifactor Leadership Questionnaire, Form 6-S (MLQ6S) was used as developed by Bass and Avolio (1992). This instrument is referred to as the most frequent and well researched and validated leadership instrument in the world (Tejeda, 2001) and is applied to a wide range of organisational settings as well as with leaders in different cultures (Bass, 1998). It is used to measure transformational leadership style systematically (Northouse, 2001). Research has demonstrated links between transformational leadership behaviours and desired organisational outcomes such as successful change. The transformational leadership scales comprise the following factors: idealised influence, individualised consideration, intellectual stimulation, and inspirational motivation (Tejeda, 2001), while the transactional scales consist of contingent reward and management-by-exception (active and passive). There is also a scale dealing with laissez-faire leadership.

Several different approaches have been used to confirm the reliability of the MLQ by examining the resulting agreement among respondents (Bass 1998). These approaches included ratererate consistency, subordinate-superior agreement, and peer ratings based on performance in small groups. In the same vein, various other types of evaluations such as performance ratings by supervisors and direct reports, as well as standard financial measures, have demonstrated a positive relationship between transformational behaviour and high MLQ ratings (Bass, 1995). In addition, similar results were found in various organisational settings when the MLQ was employed (Bass, 1995).

Substantive evidence from a number of studies conducted by Tejeda (2001), Avolio and Bass (1999), has showed that the MLQ is indeed a valid instrument across a number of validity types. Tejeda (2001) found firstly, that a reduced set of items from the MLQ appeared to show preliminary evidence of predictive and construct validity; secondly, the transformational subscales or items were highly inter-correlated in support of convergent validity; and thirdly, the transformational leadership scales were negatively related to both management-by-exception subscales and laissezfaire leadership, providing support for discriminant validity.

\section{The semi-structured interview}

For the qualitative study, a semi-structured interview, developed from descriptive, qualitative research on transformational leadership, was used. Such research has provided considerable insight pertaining to the way leaders motivate followers and influence change in organisations (Yukl, 1998). In particular, the interview was based on research by Bennis and Nanus (1997) who identified and interviewed effective leaders in an attempt to ascertain their characteristic behaviours, trait and processes of influence as well as the common themes and strategies that leaders utilise to effect change in their organisations (Yukl, 1998).

Whilst the MLQ measured three dimensions of leadership style, viz. transformational, transactional and laissez-faire leadership (Northouse, 2001), the interview assessed one dimension, viz. transformational leadership.

\section{Data collection procedure}

The sample was accessed via lists obtained from the institutions' Human Resources directors and web-sites. The questionnaire was distributed either electronically or via mail, followed by one follow-up. The instrument was self-administered, accompanied by a covering letter that provided the necessary details about the study and a self-addressed, stamped, return envelope. In order to ensure that the maximum number of questionnaires was returned, the subjects were promised a summary of the findings of the research once the study was completed. This was delivered after its completion. 
A total of 399 questionnaires were despatched and 190 of them were returned, which constituted a response rate of $47.6 \%$. In total, 86 subjects scored high on all transformational leadership behaviours, from which a total of 25 (29\%) was selected for the interview. A letter was sent to 36 of the 86 subjects requesting them to participate in the interview. A total of 11 subjects either did not respond or were unavailable for interviews, therefore leaving a total of 25 who were available for interviews, which were conducted in the subjects' offices.

The interview lasted for ten minutes. It solicited answers to five questions, namely: What are your transformational leadership strengths? What are your transformational leadership weaknesses? What past events most influenced your leadership approach? What were the critical points in your career? What are the characteristic behaviours and influences of a good transformational leader? Follow-up questions were asked for clarification or for soliciting a more straightforward answer, such as: Can you mention any other characteristic of a transformational leader and explain why? The interviews were tape-recorded and transcribed.

\section{Data analysis}

The quantitative data was analysed by a statistical consultation service connected to a university. Descriptive statistics were used to summarise patterns in the sample's responses. The statistics provided information about the frequency of the demonstration and the level (high, moderate, low) of the transformational, transactional, and laissez-faire leadership behaviours of the sample. These statistics were also used to describe the distribution of a set of data by determining the data's frequency distribution, the mean and the standard deviation (SD) (Denscombe, 2000).

Two major modes of qualitative data analysis were employed, viz. meaning condensation and hermeneutic meaning interpretation (Lee, 1999). Meaning condensation involved extracting, abridging and abstracting the most important themes from the interview texts. Hermeneutic meaning interpretation required imposing meaning on the perspective from a preexisting paradigm, viz. Bennis and Nanus' (1997) descriptive research into transformational leadership.

\section{RESULTS}

\section{Quantitative results}

Table 2 provides frequency distributions of the leaders' responses to the 21 questionnaire items as they chronologically appear in the questionnaire.

TABLE 2

LEADERS' PERCEPTION OF THEIR LEADERSHIP BEHAVIOURS

\begin{tabular}{|c|c|c|c|c|c|c|c|c|}
\hline & & & $\begin{array}{l}\text { Not at } \\
\text { all }\end{array}$ & $\begin{array}{l}\text { Once } \\
\text { in a } \\
\text { while }\end{array}$ & $\begin{array}{l}\text { Some- } \\
\text { times }\end{array}$ & $\begin{array}{l}\text { Fairly } \\
\text { often }\end{array}$ & $\begin{array}{l}\text { Fre- } \\
\text { quently, } \\
\text { if not } \\
\text { always }\end{array}$ & Total \\
\hline 1. & $\begin{array}{l}\text { I make others feel } \\
\text { good to be around } \\
\text { me. }\end{array}$ & $\begin{array}{c}\text { Count } \\
\%\end{array}$ & 1 & $\begin{array}{c}3 \\
1,6 \%\end{array}$ & $\begin{array}{c}24 \\
12,9 \%\end{array}$ & $\begin{array}{c}96 \\
51,6 \%\end{array}$ & $\begin{array}{c}63 \\
33,9 \%\end{array}$ & $\begin{array}{c}186 \\
100,0 \%\end{array}$ \\
\hline 2. & $\begin{array}{l}\text { I express with a } \\
\text { few simple words } \\
\text { what we could and } \\
\text { should do. }\end{array}$ & $\begin{array}{c}\text { Count } \\
\%\end{array}$ & $\begin{array}{c}1 \\
0,5 \%\end{array}$ & $\begin{array}{c}5 \\
2,7 \%\end{array}$ & $\begin{array}{c}26 \\
13,8 \%\end{array}$ & $\begin{array}{c}98 \\
52,1 \%\end{array}$ & $\begin{array}{c}58 \\
30,9 \%\end{array}$ & $\begin{array}{c}188 \\
100,0 \%\end{array}$ \\
\hline 3. & $\begin{array}{l}\text { I enable others to } \\
\text { think about old } \\
\text { problems in new ways }\end{array}$ & $\begin{array}{l}\text { Count } \\
\% \\
\text { s. }\end{array}$ & $\begin{array}{c}2 \\
1,1 \%\end{array}$ & $\begin{array}{c}1 \\
0,5 \%\end{array}$ & $\begin{array}{c}37 \\
19,8 \%\end{array}$ & $\begin{array}{c}90 \\
48,1 \%\end{array}$ & $\begin{array}{c}57 \\
30,5 \%\end{array}$ & $\begin{array}{c}187 \\
100,0 \%\end{array}$ \\
\hline & $\begin{array}{l}\text { I help others develop } \\
\text { themselves. }\end{array}$ & $\begin{array}{c}\text { Count } \\
\%\end{array}$ & & $\begin{array}{c}1 \\
0,5 \%\end{array}$ & $\begin{array}{c}11 \\
5,8 \%\end{array}$ & $\begin{array}{c}74 \\
39,2 \%\end{array}$ & $\begin{array}{c}103 \\
54,5 \%\end{array}$ & $\begin{array}{c}189 \\
100,0 \%\end{array}$ \\
\hline 5. & $\begin{array}{l}\text { I tell others what to } \\
\text { do if they want to } \\
\text { be rewarded for } \\
\text { their work. }\end{array}$ & $\begin{array}{c}\text { Count } \\
\%\end{array}$ & $\begin{array}{c}2 \\
1,1 \%\end{array}$ & $\begin{array}{c}11 \\
5,9 \%\end{array}$ & $\begin{array}{c}45 \\
23,9 \%\end{array}$ & $\begin{array}{c}80 \\
42,6 \%\end{array}$ & $\begin{array}{c}50 \\
26,6 \%\end{array}$ & $\begin{array}{c}188 \\
100,0 \%\end{array}$ \\
\hline b. & $\begin{array}{l}\text { I am satisfied when } \\
\text { others meet agreed- }\end{array}$ & $\begin{array}{c}\text { Count } \\
\%\end{array}$ & & & $\begin{array}{c}10 \\
5,3 \%\end{array}$ & $\begin{array}{c}48 \\
250,5 \%\end{array}$ & $\begin{array}{c}130 \\
69,1 \%\end{array}$ & $\begin{array}{c}188 \\
100,0 \%\end{array}$ \\
\hline
\end{tabular}

$\begin{array}{lllllllll}\text { 7. I am content to let } & \text { Count } & 37 & 45 & 79 & 20 & 7 & 188\end{array}$ $\begin{array}{llllllll}\text { others continue } & \% & 19,7 \% & 23,9 \% & 42,0 \% & 10,6 \% & 3,7 \% & 100,0 \%\end{array}$ working in the same way as always.

8. Others have com- Coun plete faith in me. $\%$

9. I provide appealing Count images about what $\%$ we can do.

10. I provide others with Count new ways of looking \% at puzzling things. how I think they are doing.

12. I provide recog- Coun nition/rewards $\%$ when others reach their goals.

$\begin{array}{llllllll}\text { 13. As long as things are } & \text { Count } & 14 & 30 & 91 & 37 & 13 & 185\end{array}$ working, I do not try $\quad \% \quad 7,6 \% \quad 16,2 \% \quad 49,2 \% \quad 20,0 \% \quad 7,0 \% \quad 100,0 \%$ to change anything.

$\begin{array}{llllllll}\text { 14. Whatever others } & \text { Count } & 55 & 59 & 58 & 11 & 1 & 184\end{array}$ $\begin{array}{lllllll}\text { want to do is OK } \quad \% \quad 29,9 \% & 32,1 \% & 31,5 \% & 6,0 \% & 0,5 \% & 100,0 \%\end{array}$ with me.

15. Others are proud to Count be associated with me. \%

16. I help others find Count meaning in their \% work.

17. I get others to $\%$ they had never questioned before.

18. I give personal attention to others who seem rejected.

19. I call attention to Count what others can get $\%$ for what they accomplish.

20. I tell others the to know to carry out their work.

21. I ask no more of others than what is absolutely essential. $\begin{array}{ccccc}1,1 \% & 13,3 \% & 64,1 \% & 21,5 \% & 100,0 \%\end{array}$ $\begin{array}{lllll}2 & 16 & 118 & 51 & 187\end{array}$ $1,1 \% \quad 8,6 \% \quad 63,1 \% \quad 27.3 \% \quad 100,0 \%$ $\begin{array}{llll}34 & 106 & 47 & 187\end{array}$ $18,2 \% \quad 56,7 \% \quad 25,1 \% \quad 100,0 \%$

$\begin{array}{lllllll}\text { Count } & 3 & 31 & 92 & 61 & 187\end{array}$ $1,6 \% \quad 16,6 \% \quad 49,2 \% \quad 32,6 \% \quad 100,0 \%$ $\begin{array}{ccccc}5 & 37 & 108 & 31 & 181 \\ 2,8 \% & 20,4 \% & 59,7 \% & 17,1 \% & 100,0 \%\end{array}$ $\begin{array}{lllll}2 & 19 & 97 & 68 & 186\end{array}$ $1,1 \% \quad 10,2 \% \quad 52,2 \% \quad 36,6 \% \quad 100,0 \%$

Transformational leadership behaviours: On average, all the four behaviours, viz. idealised influence, individualised consideration, intellectual stimulation, and inspirational motivation, were exhibited fairly often. The most frequently exhibited behaviour was idealised influence, i.e. $110(60,1 \%)$; followed by inspirational motivation, i.e. 109 (58,5\%); followed by intellectual stimulation, i.e. 103 (54,9\%); and lastly individualised consideration, i.e. 84 (46,0\%).

Transactional leadership behaviours: On average, the majority of leaders exhibited contingent reward fairly often, i.e. 86 (46.6\%) and management-by-exception frequently, i.e. 70 (37.6\%).

Laissez-faire leadership: On average, the majority of leaders totalling $59(31,9 \%)$ exhibited laissez-faire leadership sometimes.

Table 3 provides the measures of central tendency and dispersion.

Table 4 indicates the leaders' perceptions of their transformational, transactional and laissez-faire leadership styles as shown by the mean and the SD.

Transformational leadership: The mean is 3.14 and the SD 0.683 . The mean implies that the leaders were of the opinion that they exhibited transformational leadership fairly often. This was a relatively high level of transformational leadership exhibited by the 186 leaders who correctly completed the questionnaire. The SD measures variability around the mean. At 0.683 the SD is low against the mean of 3.14. The mean is a typical value, given that the SD is low. Typically, all leaders exhibited transformational leadership fairly often. 
TABLE 3

MEASURES OF CENTRAL TENDENCY AND DISPERSION

\begin{tabular}{|c|c|c|c|c|c|c|c|}
\hline & Valid & Missing & Mean & Median & $\begin{array}{l}\text { Std. } \\
\text { Devia- } \\
\text { tion }\end{array}$ & $\begin{array}{c}\text { Skew- } \\
\text { ness }\end{array}$ & Kurtosis \\
\hline $\begin{array}{l}\text { 1. I make others } \\
\text { feel good to be } \\
\text { around me. }\end{array}$ & 186 & 4 & 3,18 & 3,00 & 0,710 & $-0,545$ & 0,089 \\
\hline $\begin{array}{l}\text { 2. I express with a } \\
\text { few simple words } \\
\text { what we could } \\
\text { and should do. }\end{array}$ & 188 & 2 & 3,10 & 3,00 & 0,771 & $-0,813$ & 1,114 \\
\hline $\begin{array}{l}\text { 3. I enable others } \\
\text { to think about } \\
\text { old problems in } \\
\text { new ways. }\end{array}$ & 187 & 3 & 3,06 & 3,00 & 0,787 & $-0,716$ & 1,083 \\
\hline $\begin{array}{l}\text { 4. I help others } \\
\text { develop } \\
\text { themselves. }\end{array}$ & 189 & 1 & 3,48 & 4,00 & 0,632 & $-0,931$ & 0,437 \\
\hline $\begin{array}{l}\text { 5. I tell others what } \\
\text { to do if they want } \\
\text { to be rewarded } \\
\text { for their work. }\end{array}$ & 188 & 2 & 2,88 & 3,00 & 0,908 & $-0,578$ & 0,037 \\
\hline $\begin{array}{l}\text { 6. I am satisfied } \\
\text { when others meet } \\
\text { agreed-upon } \\
\text { standards. }\end{array}$ & 188 & 2 & 3,64 & 4,00 & 0,582 & $-1,377$ & 0,901 \\
\hline $\begin{array}{l}\text { 7. I am content to } \\
\text { let others continue } \\
\text { working in the } \\
\text { same way as always. }\end{array}$ & $e^{188}$ & 2 & 1,55 & 2,00 & 1,041 & 0,130 & $-0,405$ \\
\hline $\begin{array}{l}\text { 8. Others have com- } \\
\text { plete faith in me. }\end{array}$ & 184 & 6 & 3,11 & 3,00 & 0,600 & $-0,197$ & 0,383 \\
\hline $\begin{array}{l}\text { 9. I provide ap- } \\
\text { pealing images } \\
\text { about what we } \\
\text { can do. }\end{array}$ & 186 & 4 & 2,98 & 3,00 & 0,670 & $-0,309$ & 0,222 \\
\hline $\begin{array}{l}\text { 10. I provide others } \\
\text { with new ways } \\
\text { of looking at } \\
\text { puzzling things. }\end{array}$ & 187 & 3 & 3,07 & 3,00 & 0,668 & $-0,414$ & 0,413 \\
\hline $\begin{array}{l}\text { 11, I let others know } \\
\text { how I think they } \\
\text { are doing. }\end{array}$ & 186 & 4 & 3,23 & 3,00 & 0,722 & $-0,718$ & 0,412 \\
\hline $\begin{array}{l}\text { 12, I provide recog- } \\
\text { nition/rewards } \\
\text { when others reach } \\
\text { their goals. }\end{array}$ & 186 & 4 & 3,42 & 4,00 & 0,680 & $-0,873$ & 0,029 \\
\hline $\begin{array}{l}\text { 13. As long as things } \\
\text { are working, I do } \\
\text { not try to change } \\
\text { anything. }\end{array}$ & 185 & 5 & 2,03 & 2,00 & 0,975 & $-0,090$ & 0,058 \\
\hline $\begin{array}{l}\text { 14. Whatever others } \\
\text { want to do is OK } \\
\text { with me. }\end{array}$ & 184 & 6 & 1,15 & 1,00 & 0,940 & 0,289 & $-0,730$ \\
\hline $\begin{array}{l}\text { 15. Others are proud } \\
\text { to be associated } \\
\text { with me. }\end{array}$ & 181 & 9 & 3,06 & 3,00 & 0,625 & $-0,319$ & 0,592 \\
\hline $\begin{array}{l}\text { 16. I help others find } \\
\text { meaning in their } \\
\text { work. }\end{array}$ & 187 & 3 & 3,17 & 3,00 & 0,613 & $-0,392$ & 0,822 \\
\hline $\begin{array}{l}\text { 17. I get others to } \\
\text { rethink ideas that } \\
\text { they had never } \\
\text { questioned before. }\end{array}$ & 187 & 3 & 3,07 & 3,00 & 0,656 & $-0,072$ & $-0,662$ \\
\hline $\begin{array}{l}\text { 18. I give personal } \\
\text { attention to others } \\
\text { who seem rejected. }\end{array}$ & 187 & 3 & 3,13 & 3,00 & 0,737 & $-0,452$ & $-0,276$ \\
\hline $\begin{array}{l}\text { 19. I call attention to } \\
\text { what others can } \\
\text { get for what they } \\
\text { accomplish. }\end{array}$ & 181 & 9 & 2,91 & 3,00 & 0,694 & $-0,386$ & 0,321 \\
\hline $\begin{array}{l}\text { 20.I tell others the } \\
\text { standards they } \\
\text { have to know to } \\
\text { carry out their work }\end{array}$ & 186 & 4 & 3,24 & 3,00 & 0,674 & $-0,547$ & 0,152 \\
\hline $\begin{array}{l}21, \text { I ask no more of } \\
\text { others than what is } \\
\text { absolutely essential. }\end{array}$ & $s^{184}$ & 6 & 1,58 & 1,00 & 1,247 & 0,393 & $-0,860$ \\
\hline
\end{tabular}

TABLE 4

THE MEAN AND SD INDICATING THE LEADERS' PERCEPTION OF THEIR TRANSFORMATIONAL, TRANSACTIONAL AND LAISSEZ-FAIRE LEADERSHIP STYLES

\begin{tabular}{lcccc}
\hline Variable & Valid & Missing & Mean & $\begin{array}{c}\text { Std } \\
\text { Deviation }\end{array}$ \\
\hline Transformational Leadership & 186 & 4 & 3,14 & 0,683 \\
Transactional Leadership & 186 & 4 & 3,02 & 0,752 \\
Laissez-faire Leadership & 185 & 5 & 1,38 & 1,076 \\
\hline
\end{tabular}

Transactional leadership: The mean is 3.02 and the SD is 0.752 , The mean implies that leaders held the view that they exhibited transactional leadership fairly often. This was also a relatively high level of transactional leadership exhibited by the 186 leaders who correctly completed the questionnaire. At 0.752 the $\mathrm{SD}$ is low against the mean of 3.02, implying that there is little variation around the mean. That is, the mean is a typical value, given that the SD is low. Typically, all leaders exhibited transactional leadership fairly often.

Laissez-faire leadership: The mean is 1,38 and the SD is 1,076 . The mean implies that the leaders held the opinion that they exhibited laissez-faire leadership once in a while. This was a very low level of laissez-faire leadership exhibited by the 186 leaders who correctly completed the questionnaire. At 1,076 the SD is high against the mean of 1,38 . This implies that there is more variability around the mean. As a result, the assertion that leaders exhibited laissez-faire leadership once in a while varies from leader to leader or is not typical among all the leaders.

The results of the quantitative study showed that on average, the level of transformational leadership is more or less the same as the level of transactional leadership, as leaders exhibited these styles of leadership fairly often. This is in line with Bass' view that transformational leadership augments transactional leadership (Tejeda, 2001, 35) - what is referred to as the transformational/transactional continuum. The low level of laissez-faire leadership indicates that leaders did not exhibit nonleadership, which is positive vis-à-vis their ability to manage change successfully.

\section{Qualitative findings}

Leaders employed five themes or strategies in effecting change in their organisations. Firstly, they utilised their transformational leadership strengths, which included people orientation, sensitivity to the macro-environment, the ability to manage diversity and to engage in two-way communication, exposure to transformational leadership, religious beliefs, and having a vision. Secondly, they displayed weaknesses which included impatience, inability to reverse decisions, poor communication owing to a language barrier, avoidance of conflict, being forthright, and a perfectionist attitude. Thirdly, they were guided by the past events that most influenced their leadership approach. These include family and mentor influences and assumptions regarding leadership roles. Fourthly, they were guided by critical points in their careers which included appointment and promotion, making unpopular decisions, receiving rewards, and undertaking and completing important projects. Fifthly, they utilised certain cognitive, affective, motivational, and interpersonal behaviours and influences that characterise a good transformational leader.

\section{DISCUSSION}

The quantitative study indicated that these particular leaders exhibited transformational leadership and its behaviours 
fairly often, which is a relatively high level. In addition, the level of transformational leadership is relatively high, thereby implying that these leaders can manage change fairly successfully. The ideal situation, however, would be for leaders to exhibit these behaviours frequently if not always. They also exhibited transactional leadership behaviours fairly often and frequently, which indicated that they are transactional in their leadership approach. Similarly, they exhibited transactional leadership fairly often, which is also at a relatively high level, thereby implying that these leaders lead by the exchange relationship they have with their followers. They further exhibited laissez-faire leadership once in a while, which is at a very low level, with variations from one leader to another.

The qualitative study indicated that these leaders employed the following five themes or strategies in effecting change in their organisations.

\section{The transformational leaders' strengths}

The leaders were people-oriented in terms of knowing what happens in their followers' lives; caring for them by way of empathising with them during trying times and not becoming detached from their problems; motivating them by way of creating a climate conducive to optimal functioning; and standing up for them and taking blame for their mistakes. They also displayed sensitivity to the macro-environment in terms of embracing, monitoring and having a passion for change. They were aware of and sensitive to the changes taking place in the environment in which they operate. Bennis and Nanus (1997) established in this regard that transformational leaders develop conscious awareness of environmental changes and trends (Yukl, 1998) in their efforts to manage change.

The leaders possessed the ability to manage diversity. This should have made the followers feel, irrespective of their diverse backgrounds, that they were an inseparable part of a worthwhile enterprise (Bennis \& Nanus, 1997; Northouse, 2001; Yukl, 1998). Coupled with this was the ability to engage in two-way communication and adopt an open-door policy, which is a basic ingredient for developing trust between the leader and the follower and is a "golden line in every organisation". Inspirational motivation includes developing and communicating an appealing vision (Avolio, 1994) so as to focus the efforts of followers. Leaders communicate high expectations or give pep talks (Bass \& Avolio, 1992) to followers and thereby inspire them to become more committed to the organisation and allow them to communicate their feelings and ideas freely.

They were also exposed to transformational leadership and read up extensively on this leadership style. The process perspective on leadership contends that leadership can be observed in leader behaviours and can be learned (Northouse, 2001). Bennis and Nanus (1997) established that transformational leaders are able to sharpen their skills and enhance the knowledge they have gained from experiences of success and failure by recognising the importance of continually gathering information about changing and uncertain events. They also create a network of information and take the initiative as regards special organisational studies of the information gathering needed for strategic planning (Yukl, 1998). Leaders are committed to learning and relearning (Bass, 1990), including consistent emphasis on education in the organisation (Northouse, 2001).

The leaders displayed strong religious beliefs, especially that of Christianity. They saw their leadership style as being a result of their religion and not of their own control over events that affected their lives. Their locus of control was thus external in that they attributed outcomes to circumstances beyond their control. They also possessed a clearly articulated and appealing vision (Hughes et al., 1999). Having vision is a necessary condition to be met for transformational leadership (Yukl, 1998), since vision is necessarily a commodity of leaders (Bennis \& Nanus, 1997).

\section{The transformational leaders' weaknesses}

The leaders often became impatient with processes and people and wanted to see change happen overnight. They disliked red tape ("seven signatures before leave could be approved", "long communication lines", many policies and procedures channelling them into a certain mode of thinking). They wanted things done immediately.

They also felt unable to reverse decisions and, as such, exhibited rigid behaviour. The Whites experienced poor communication due to a language barrier, especially with regard to their lack of knowledge of an indigenous language spoken by their followers, thereby making it difficult to build rapport, trust, and a sense of belongingness with them. This is a diversity issue in which one group (White) was unable to connect with another (Black).

They further tended to avoid conflict with their followers. When followers did not perform, the leaders did not show dissatisfaction. Instead, they corrected the mistakes committed by their followers or else they did the actual work supposed to have been done by the latter. Avoidance of conflict is but one tactic leaders employ in handling dysfunctional conflict, which is the kind of conflict that threatens the organisation's interest (Kreitner \& Kinicki, 1998). Avoidance might be suitable for trivial issues or when the costs of confrontation outweigh the benefits of resolving the conflict. It is, however, inappropriate for difficult and worsening problems. The committing of mistakes should also be viewed in a positive light. Bennis and Nanus (1997) established that leaders viewed mistakes as being a normal part of doing things and used them as windows of opportunity for learning and development purposes (Yukl, 1998). Bass (1998) also found that transformational leaders came from backgrounds in which it was acceptable to fail as long as a person tried his/her best and in which mistakes were considered part of learning.

Paradoxically, the leaders tended to be forthright and did not avoid conflict, irrespective of whether some people might get hurt in the process. They believed in "telling it like it is". This implied being inconsiderate, inhumane, disrespectful, unreasonably confrontational, "devilish", not caring, and lacking people skills. If this perception were true, then it deserved to be classified as a weakness on the part of the leaders. However, if being forthright was perceived as being genuinely wanting to achieve the organisational objectives, manage change effectively and efficiently, and create functional conflict, then it constitutes a strength.

They also perceived themselves as being too perfectionist in attitude and actions. As a result, they struggled with delegating matters. They could not risk leaving important things in the hands of other people, lest they made mistakes. They also tended to adhere strictly to deadlines and preferred to spend sleepless nights rather than be beaten by deadlines. This perfectionist attitude is an obsession which makes them compulsive in behaviour.

\section{Past events that most influenced the leaders' leadership approach}

Relevant experiences acquired early in life appear to contribute to one's emergence as a transformational leader in adulthood (Bass, 1998). Dozens of important individual events shape individuals' lives and contribute significantly to their ethical beliefs and behaviour (Griffin, 1996). These events are not isolated but are a normal and routine part of growing up and maturing. 
The leaders attributed their leadership style to family influences. Their parents used to set high standards and they set high standards for themselves too. They were also brought up in "liberal households". Avolio and Gibbon (1988, cited in Bass, 1998) found that neither a severely disadvantaged nor a highly privileged childhood was conducive to becoming a transformational leader. Instead, most conducive was a childhood with some moderate challenges. Transformational leadership also represents an ethical and moral exercise as it essentially raises the level of human conduct and motivation (Northouse, 2001). People begin to form ethical standards as children in response to the behaviours of their parents and the behaviours that their parents allow them to choose.

The leaders also attributed their leadership style to mentor influences. The mentor-protégé relationship is important in developing a high-performance culture, including employee development and effective organisational communication (Kreitner \& Kinicki, 1998). Mentoring is like individualised consideration which indicates the degree to which the leaders show interest in others' well-being, assign projects individually, and pay individual attention to those who seem less involved in the group (Northouse, 2001). On the contrary, leaders who were faced with stressful conflict with their bosses had their intellectual functioning impaired (Fiedler \& Lester, 1977, cited in Bass, 1985).

The leaders were made to assume leadership roles at an early age, especially when they were still at school or university, such as being a herd-boy, the captain of various sports teams, the head student of a hostel and an SRC president. According to Bass (1998) transformational leaders were found to have engaged in more leadership activities in high school and college. Their school-age experiences revealed that they were almost always leaders of the gang or "clique", which was a precursor of charismatic-inspirational leadership. Those higher in individualised consideration either encouraged others to talk to them about their personal problems or were told about personal problems by others. They had also been more involved in high school sports activities, particularly team sports, in their early life (Yammarino \& Bass, 1990, cited in Bass, 1998).

\section{Critical points in the leaders' career}

The leaders cited their appointment and promotion as critical points. These constitute a form of motivation and make an individual happy, satisfied, and inspired to go the extra mile in making meaningful contributions to the organisation. Finding a job, particularly in the hostile and unreceptive job market, is payback time for all the hard work and sacrifices made during school and university days.

The leaders also made unpopular decisions. One does not have to "buy face" or "run a popularity campaign" by making decisions that will be accepted by everyone. They considered themselves to be strong enough and to display sufficient character to make unpopular decisions, as long as those decisions were justifiably sound. Transformational leaders will, firstly, not make decisions haphazardly, as in the case of a "garbage model" of decision-making; secondly, they will not be channelled by bounded rationality in which they are bound or restricted by a variety of constraints that reduce rational thinking; and thirdly, they will not subscribe to groupthink in which cohesive in-groups allow the desire for unanimity to override sound judgment (Kreitner \& Kinicki, 1998).

The reception of awards in recognition of their achievements or of work well done and the undertaking and completion of important projects were cited as critical points. These boosted the leaders' morale and inspired them to achieve even more. As a result, team spirit is aroused and enthusiasm and optimism are displayed (Bass, 1998).
Characteristic behaviours and influences of a good transformational leader

Cognitive behaviour is based on a perspective that emphasises thinking as the key element (Davis \& Palladino, 1997) in causing behaviour, and involves understanding and knowing (Groome, Dewart, Esgate, Gurney, Kemp \& Towell, 2001). The leader exhibiting cognitive behaviour keeps his/her ear to the ground, monitors the environment, and aligns him/herself with progressive thinking in the industry. He/she is a scholar and keeps abreast with developments in the fields of leadership and change management.

Affective behaviour involves an individual's feelings and emotions which result from his/her beliefs about a person, object or situation (Gordon, 1996). The leader perceives a vision of where he/she wants to take the organisation and displays patience in dealing with transformational issues. The leader also exhibits charisma, which is a necessary ingredient for attaining unequivocal follower support, and displays innovation and creativity, which are necessary for managing unpredictable change situations.

Motivational behaviour encompasses those psychological processes that cause the arousal, direction and persistence of voluntary, goal-directed actions (Kreitener \& Kinicki, 1998). The leader is able to motivate his/her followers to see the necessity to change to the new paradigm that must be followed, and acknowledges that people possess inherent strengths and that they should be convinced and not coerced.

Interpersonal behaviour involves the ability to communicate with, understand, and motivate both individuals and groups (Gordon, 1996). The leader is a good listener and is able to communicate well and translate into acceptable language what people are putting too strongly. $\mathrm{He} / \mathrm{she}$ is both people-oriented and results-driven, thereby balancing the needs of the followers and those stemming from the tasks to be performed in order to achieve the desired results.

\section{Conclusions}

The leaders investigated in this study have been found to exhibit transformational leadership and its behaviours fairly often, which is a relatively high level. Also, the level of transformational leadership is relatively high, hence implying that the leaders can manage change fairly successfully. The ideal situation, however, would be one in which leaders exhibit these traits frequently if not always.

Transformational leadership is shaped by the leaders' strengths and weaknesses, in which they dwell more on their strengths than on their weaknesses, the past events that most influenced their leadership approach, critical points in their careers, and the characteristic behaviours (cognitive, affective, motivational, and interpersonal) that define good transformational leaders, with the consequent ability to manage change.

The findings indicate that the picture painted about leadership is not as bleak as it has been made to be. Therefore, the perception that there is a lack of effective leadership among leaders in the HE sector is not that accurate.

\section{Recommendations}

Recommendations to facilitate these leaders' transformational leadership, which is manifested frequently if not always, include the following.

Firstly, coaching in transformational leadership could help to equip leaders with those behaviours lacking in their repertoire. Coaching is a people-focussed form of development (Mathews, 1997) and an open-ended process that analyses the present situation, defines the performance goal, and combines personal, organisational and external resources with the purpose of implementing a plan to reach that goal (King \& Eaton, 1999). 
Coaching can be performed in terms of different paradigms. Although accredited MLQ Coaching is desirable, coaching from the systems psychodynamic stance (Cilliers, 2005) could equip the leader in terms of awareness of diversity dynamics and conflict management.

Secondly, training in HE leadership would have to be carried out via the Higher Education Leadership and Management Programme (HELM). The HELM is a direct response to the purported sectoral leadership and management capacity needs. Its aim is to guide, assist and support HE leadership in successfully navigating the constant challenges of change. It explores and creates dynamic solutions that address organisational and individual capacity gaps in HE leadership (Higher Education Leadership and Management Programme, 2004).

Thirdly, in-house leadership training, in which internal experts or external consultants on leadership are tasked to design training programmes that are tailored to the needs of the particular institution, is recommended. The HELM and in-house training should be used to supplement coaching.

Lastly, it is suggested that the findings of this research be extended to other sectors in the public and private domains.

\section{Limitations}

The generalisability of the results could be limited because of the short 21-item MLQ-6S, the primary sampling units which excluded HE institutions that were not involved in the merger processes, the use of descriptive statistics in processing quantitative data and because analysis of variance (ANOVA) was not used. Also, the self-administration mode of the questionnaire could have enhanced the subjectivity of responses.

\section{REFERENCES}

Avolio, B.J. (1994). The alliance of Total Quality and the full range of leadership. In B.M. Bass \& B.J. Avolio. (Eds.). Improving organisational effectiveness: Through transformational leadership. Thousand Oaks, CA: SAGE.

Avolio, B.J. (1999). Full leadership development: Building the vital forces of organisations. Thousand Oaks, CA: SAGE.

Avolio, B.J. \& Bass, B.M. (1999). Re-examining the components of transformational and transactional leadership using the Multifactor Leadership Questionnaire. Journal of Occupational \& Organisational Psychology, 72 (4), 441-462,

Babbie, E. \& Mouton, J. (2001). The practice of social research. Cape Town: Oxford University Press.

Bass, B.M. (1985). Leadership and performance beyond expectations. New York: The Free Press.

Bass, B.M. (1990). Bass and Stodgill's handbook of leadership: Theory, research and managerial application. New York: The Free Press.

Bass, B.M. (1995). From transactional to transformational leadership: Learning to share a vision. In R.M. Steers, L.W. Poter \& G.A Bigley (Eds.). Motivation and leadership at work. (6 $6^{\text {th }}$ Ed.). New York: McGraw-Hill: 628-640.

Bass, B.M. (1998). Transformational leadership: Industrial, military, and educational impact. Mahwali, NJ: Lawrence Erlbaum Associates.

Bass, B.M. \& Avolio, B.J. (1992). Developing transformational leadership: 1992 and beyond. Journal of European Industrial Training, 14 (5), 21-27.

Bass, B.M. \& Avolio, B.J. (1994). Introduction. In B.M. Bass \& B.J. Avolio. (Eds.). Improving organisational effectiveness: Through transformational leadership. Thousand Oaks, CA: SAGE.

Bass, B.M. \& Avolio, B.J. (2001). Shatter the glass ceiling: Women may make better managers. In K. Grint (Ed). Leadership: Classical, contemporary, and critical approaches. Oxford: Oxford University Press.
Bennis, W. \& Nanus, B. (1997). Leaders: The strategies for taking charge. New York: Harper and Row.

Brunyee, L.R. (2001). Managing in the rapidly changing context of higher education: A manager, as reflective practitioner, reflects on some experiences. In P. Higgs (Ed.). South African Journal of Higher Education, 15 (2), 8-12,

Burns, J.M. (1978). Leadership. New York: Harper \& Row.

Cilliers, F. (2005). Executive coaching experiences. A systems psychodynamic perspective. South African Journal of Industrial Psychology, 31 (3), 23-30.

Cloete, N., Bunting, I. \& Kulati, T. (2000). Higher education and leadership challenges in 1999. In N. Cloete, I. Bunting \& T. Kulati. (Eds.). Leadership and institutional challenges in higher education. Pretoria: Centre for Higher Education Transformation.

Conger, J.A. \& Kanungo, R.N. (1998). Charismatic leadership in organisations. Thousand Oaks, CA: SAGE.

Creswell, J.W. (1994). Research design: Qualitative \& quantitative approaches. Thousand Oaks, CA: SAGE.

Davis, S.F. \& Palladino, J.J. (1997). Psychology. New Jersey: Prentice Hall, Upper Saddle River.

Dawson, P. (1994). Organisational change: A processual approach. London: Paul Chapman.

Denscombe, M. (2000). The good research guide: For small-scale social research projects. Burkingham: Open University Press.

Department of Education. (1997). Higher Education Act, No 101 of 1997. Pretoria: Government Printers.

Department of Education. (2001). National Plan for Higher Education. Pretoria: Government Printers.

Engelbrecht, A.S. (2002). The effect of organisational leadership on value congruence and effectiveness: An integrated model. In S.M. Brink. (Ed.). South African Journal of Economic and Management Sciences. Pretoria. University of Pretoria. 5 (3), 589-608.

File, J. (2000). A comparative perspective on leadership and institutional change. In N. Cloete, I. Bunting \& T. Kulati. (Eds.). Leadership and institutional challenges in higher education. Pretoria: Centre for Higher Education Transformation.

Gordon, J.R. (1996). Organisational behaviour: A diagnostic approach. New Jersey: Prentice Hall International.

Griffin, R.W. (1996). Management. Boston: Houghton Mifflin.

Groome, D.; Dewart, H.; Esgate, A.; Gurney, K.; Kemp, R. \& Towell, N. (2001). An introduction to cognitive psychology: Processes and disorders. East Sussex: Psychology Press.

Handford, J.S. (1999). Essential transformational leadership skills to mobilise people. Unpushed MBA dissertation. Potchefstroom: PU for CHE.

Higher Education Leadership and Management Programme. (2004). Available from: www.sauvca.org.za/keyprojects/ (Accessed on 7 July 2004).

Hughes, R.L., Ginnet, R.C. \& Curphy, G.L. (1999). Charisma and transformational leadership. Leadership: Enhancing lessons from experiences. Boston: Irwin/McGraw-Hill: 285-326.

Jansen, J.D. (2001). Does the national plan effectively address the critical issues facing higher education? In J.D. Jansen. (Ed.). South African Journal of Higher Education, 15 (3), 5-9.

King, P \& Eaton, J. (1999). Coaching for results. Industrial and commercial training, 31 (4), 145-148.

Kreitner, R. \& Kinicki, A. (1998). Organisational behaviour. Boston: McGraw-Hill.

Lee, T.W. (1999). Using qualitative methods in organizational research. Thousand Oaks, CA: SAGE.

Matthews, S. (1997). Mentoring and coaching: The essential leadership skills. London: FT Pitman.

McLagan, P. (2002). Change leadership today: Why we need to rethink change. In R. Havenga. (Ed.). Management today, 18 (7), 4-6.

Nicholson, N. (1993). Organisational change. In C. Mabey \& B. Mayon-White. (Eds.). Managing change. London: Paul Chapman. 
Norris, B.D. (2001). Transformation, diversity and organisational change within institutions of higher education. South African Journal of Education, 21 (3), 219-222,

Northouse, P.G. (2001). Leadership: Theory and practice. Thousand Oaks, CA: SAGE.

Paton, R.A. \& McCalman, J. (2001). Change management: A guide to effective implementation. London: SAGE.

Tejeda, M.J. (2001). The MLQ revisited: Psychometric properties and recommendation. Leadership Quarterly, 12 (1), 31-52.

Van Rensburg, C. \& Crous, F. (2000). Die verband tussen sekere persoonlikheidseienskappe en transformasionele leierskap. Journal of industrial psychology, 26 (3), 39-46.
Van Rooyen, G. (2000). Strategising and managing in a crisis: Lessons from the Public Sector. In N. Cloete, I. Bunting \& T. Kulati. (Eds.). Leadership and institutional change in higher education. Pretoria: Centre for Higher Education Transformation.

Van Staden, J.F; Scheepers, J.M. \& Rieger, H.S. (2000). Lokus van beheer en transformasionele leierskap. Journal of industrial psychology, 26 (3), 8-14.

Van Tonder, H. (1998). The effect of transformational leadership on organisational culture. Unpublished DCom thesis. Johannesburg: RAU.

Yukl, G. (1998). Leadership in organisations. Englewood Cliffs: Prentice-Hall. 